\title{
THE EFFECT OF CROSSING OF DOMESTIC SIMMENTAL BREED AND FRENCH FATTENING BREEDS ON CONFORMATION AND FAT COVER OF BEEF CARCASSES
}

\author{
D. Ostojič-Andrić ${ }^{1}$, S. Aleksić ${ }^{1}$, M. M. Petrović ${ }^{1}$, S. Hristov ${ }^{2}$, V. \\ Pantelić $^{1}$, Ž. Novaković ${ }^{1}$, D. Nikšić ${ }^{1}$
}

\footnotetext{
${ }^{1}$ Institute for Animal Husbandry, Autoput 16, P. Box 23, 11080, Belgrade-Zemun, Republic of Serbia

${ }^{2}$ Faculty of Agriculture, Nemanjina 6, 11080, Belgrade-Zemun, Republic of Serbia

Corresponding author: andricdusica.iah@gmail.com

Original scientific paper
}

Abstract: Evaluation of conformation and fat cover of beef carcasses has great importance in modern systems of carcass quality evaluation. In this way, adequate price is achieved for every classified carcass side according to market demand. In this paper, the effect of experimental crossing of Domestic Simmental breed with Charolais and Limousine breed $(\mathrm{N}=96)$ on conformation and fat cover was investigated. Evaluation was carried out on the whole carcass and partially for certain parts of carcass according to special evaluation pattern/form (1-5). In regard to evaluation of carcass conformation, statistically significant differences $(p<0,01)$ were established between crosses and Domestic Simmental breed. Crosses with Charolais achieved the highest score for conformation $(3,94)$, the highest score for round conformation $(3,77)$ and shoulder $(4,06)$. Considerably more fat tissue on outside of the carcass was determined in Domestic Simmental breed $(3,44)$ compared to crosses with Charolais $(3,27)$. Presence of fat in pelvic cavity was more expressed in Charolais $(3,34)$ and Limousine crosses $(3,28)$, with better score for covering of kidneys $(3,50$ and 3,53$)$ compared to Domestic breed $(3,17)$.

Key words: fattening breeds, crossing, carcass, conformation, fat cover

\section{Introduction}

Evaluation of conformation and cover of beef carcasses with fat is very important in modern systems of the evaluation of carcass quality (e.g. SEUROP classification, USDA Beef grade, etc). In this way, adequate score or each graded carcass side is realized according to the demands on the market. Importance of application of said grades is also in achievement of genetic progress in population of fattening cattle, since breeders are stimulated to rear animals from which explicit 
meatiness and equal cover of carcass can be expected in case of moderate to medium presence of fat.

Correct evaluation of conformation can result in indirect obtaining of information about the development of high quality muscles sections on the carcass (round, loin, back), as well as meat : bone ratio. In practice, the opinion is generally accepted that roundness and width of carcass is formed by musculature, whereas in the length of carcass bones participate predominantly. Significance of the evaluation of carcass cover with fat reflects in the effect of this trait on technological and nutritive meat properties. Namely, subcutaneous fat tissue isolates the carcass and slows down post-mortal cooling, mitigating the effect of so called »cold-shortening « and improves the meat tenderness. On the other hand, high correlation between cover of carcass with fat and content of intra muscular fat is present (May et al., 1992) so in spite of positive effect on cooling loss and meat tenderness, high amounts of exterior fat on animal carcass cannot be considered desirable.

In research by Aleksić et al. (1999), Chambaz et al. (2003) and Dhuyvetter et al. (1985), genotype is pointed out as factor of significant importance on improvement of conformation and cover of carcass with fat. Industrial crossing is fast and efficient way, by way of heterosis and complementarity, improve said properties in progeny of F1 generation (Ostojić-Andrić et al., 2008). According to studies by Marshall (1994), heterosis for carcass cover with fat was $10,1 \%$.

In this research the effects of experimental crossing of domestic Simmental cattle and Charolais and Limousine breed cattle on conformation and beef carcass cover with fat.

\section{Materials and Methods}

For research purposes, total of 96 fattening cattle were divided into three genotype groups (G1-G3) with 32 heads in each one: G1-young cattle of domestic Simmental breed (DS) as control group; G2-crosses of F1 generation of DS x Limousine and G3-crosses of F1 generation of DS $\times$ Charolais. Young male cattle at 155-165 age of days and 175-220 kg body weight were included in experiment. They were housed in free system, fed concentrated feed, hay and maize silage ad libitum (Table 1) to the certain degree of fattening and approximate body mass of $600 \mathrm{~kg}$.

The average duration of fattening was 295 days. At the end of fattening all heads were slaughtered in experimental abattoir of the Institute for Animal Husbandry, Belgrade-Zemun. Evaluation of conformation and fat cover was done on beef carcasses without skin (no trimming), head, lower leg parts, tail and internal organs, $24 \mathrm{~h}$ subsequent to cooling $\left(0-4^{\circ} \mathrm{C}\right)$. 
Table 1. Feeding regime durring the fattening

\begin{tabular}{|c|c|c|c|}
\hline \multirow[t]{2}{*}{ Feeds } & \multicolumn{3}{|c|}{ Body weight, $\mathrm{kg}$} \\
\hline & to 220 & $\begin{array}{l}\text { from } 220 \\
\text { to } 300\end{array}$ & over 300 \\
\hline \multicolumn{4}{|l|}{ Concentrate mixture composition, $\%$} \\
\hline Dry corn & 48.6 & 65.7 & --- \\
\hline Corn grain silage & --- & --- & 60 \\
\hline Wheat middlings & 15 & 10 & 15.3 \\
\hline Sunflower meal & 20 & 16.2 & 21 \\
\hline Soyabean meal & 13 & 5 & --- \\
\hline Di-Calciumphosphate & 0.3 & 0.1 & 0.2 \\
\hline Calciumcarbonate & 1.6 & 1.5 & 1.5 \\
\hline Salt & 0.5 & 0.5 & 1 \\
\hline Premix & 1 & 1 & 1 \\
\hline Mean amount, kg/day & 3 & 5 & 9 \\
\hline Mean amount, $\mathrm{kg} / 100 \mathrm{~kg}$ body weight & 1.5 & 1.9 & 1.5 \\
\hline \multicolumn{4}{|l|}{ Whole plant maize silage } \\
\hline Mean amount, kg/day & 5 & 10 & 15 \\
\hline Mean amount, $\mathrm{kg} / 100 \mathrm{~kg}$ body weight & 2.5 & 3 & 2.5 \\
\hline \multicolumn{4}{|l|}{ Medium quality hay } \\
\hline Mean amount, kg/day & 1 & 2 & 0 \\
\hline Mean amount, $\mathrm{kg} / 100 \mathrm{~kg}$ body weight & 0.5 & 0.75 & 0 \\
\hline
\end{tabular}

Evaluation of carcasses in sense of conformation and fat cover was done visually according to determined linear scale scores (Scheme 1) by professional board in order to avoid the subjectivity of the score. Carcass conformation was evaluated partially through individual score of the development of round, central carcass part (back, loin and pelvis) and shoulder part, and subsequently, these scores were presented through total conformation score. Fat carcass cover was scored based on layer on carcass and depots in thoracic and pelvic cavity. Scale used for scoring conformation and fat carcass cover is presented in. 
Scheme 1. Linear evaluation of fat cover and conformation score

\begin{tabular}{|c|c|c|c|c|c|}
\hline \multirow[b]{2}{*}{$\begin{array}{l}\text { Carcass } \\
\text { parts }\end{array}$} & \multicolumn{5}{|c|}{ Conformation scores } \\
\hline & $\begin{array}{c}5 \\
\text { excellent }\end{array}$ & $\begin{array}{c}4 \\
\text { very good }\end{array}$ & $\begin{array}{c}3 \\
\text { good }\end{array}$ & $\begin{array}{c}2 \\
\text { medium } \\
\end{array}$ & $\begin{array}{c}1 \\
\text { poor }\end{array}$ \\
\hline Profiles & $\begin{array}{c}\text { Convex to super } \\
\text { convex }\end{array}$ & $\begin{array}{l}\text { Convex in } \\
\text { whole }\end{array}$ & $\begin{array}{l}\text { Straight in } \\
\text { whole }\end{array}$ & $\begin{array}{l}\text { Straight to } \\
\text { concave }\end{array}$ & $\begin{array}{c}\text { Concave to very } \\
\text { concave }\end{array}$ \\
\hline Round & Very round & Round & Well developed & $\begin{array}{c}\text { Insufficiently } \\
\text { developed }\end{array}$ & $\begin{array}{c}\text { Poorly } \\
\text { developed }\end{array}$ \\
\hline Back & $\begin{array}{l}\text { Wide and very } \\
\text { full }\end{array}$ & Wide and full & Full & $\begin{array}{c}\text { Insufficiently } \\
\text { full }\end{array}$ & $\begin{array}{l}\text { Narrow with } \\
\text { visible bones }\end{array}$ \\
\hline \begin{tabular}{|l|} 
Shoulder \\
strip
\end{tabular} & Very round & Round & Well developed & $\begin{array}{l}\text { Average to } \\
\text { almost flat }\end{array}$ & $\begin{array}{c}\text { Flat with } \\
\text { visible bones }\end{array}$ \\
\hline \begin{tabular}{|l|} 
Interior \\
round \\
section
\end{tabular} & $\begin{array}{c}\text { Distinctly above } \\
\text { symphysis }\end{array}$ & $\begin{array}{c}\text { Above } \\
\text { symphysis }\end{array}$ & Poorly round & $\begin{array}{l}\text { Almost flat } \\
\text { profile }\end{array}$ & Flat profile \\
\hline \begin{tabular}{|l|} 
Pelvic \\
section
\end{tabular} & Very round & Round & Poorly round & $\begin{array}{c}\text { Almost flat } \\
\text { profile }\end{array}$ & Flat profile \\
\hline & \multicolumn{5}{|c|}{ Carcass fat cover score } \\
\hline $\begin{array}{l}\text { Carcass } \\
\text { parts }\end{array}$ & $\begin{array}{c}1 \\
\text { low }\end{array}$ & $\begin{array}{c}2 \\
\text { slight }\end{array}$ & $\begin{array}{c}3 \\
\text { medium }\end{array}$ & $\begin{array}{c}4 \\
\text { high }\end{array}$ & $\begin{array}{c}5 \\
\text { excessive }\end{array}$ \\
\hline Carcass & $\begin{array}{l}\text { Insignificant or } \\
\text { poor }\end{array}$ & $\begin{array}{l}\text { Poor, meat } \\
\text { mainly visible }\end{array}$ & $\begin{array}{c}\text { Round and } \\
\text { withers, meat is } \\
\begin{array}{c}\text { almost totally } \\
\text { covered }\end{array}\end{array}$ & $\begin{array}{l}\text { Good cover, } \\
\text { Except round } \\
\text { and withers }\end{array}$ & Fully covered \\
\hline Round & $\begin{array}{l}\text { Insignificant or } \\
\text { poor }\end{array}$ & $\begin{array}{l}\text { Poor, meat } \\
\text { mainly visible }\end{array}$ & Poorly covered & $\begin{array}{c}\text { Fat sutures } \\
\text { distinct }\end{array}$ & \begin{tabular}{|c|} 
Almost totally \\
covered, \\
sutures are not \\
visible \\
\end{tabular} \\
\hline Chest cavity & No fat & $\begin{array}{l}\text { Rib muscles } \\
\text { clearly visible }\end{array}$ & $\begin{array}{c}\text { Small fat depots, } \\
\text { and rib muscles } \\
\text { clearly visible }\end{array}$ & $\begin{array}{l}\text { More distinct fat } \\
\text { depots, rib } \\
\text { muscles } \\
\text { permeated with } \\
\text { fat }\end{array}$ & $\begin{array}{c}\text { Large fat depots, } \\
\text { rib muscles } \\
\text { strongly } \\
\text { permeated with } \\
\text { fat }\end{array}$ \\
\hline $\begin{array}{l}\text { Pelvic } \\
\text { cavity }\end{array}$ & No fat & $\begin{array}{l}\text { Small amounts } \\
\text { of fat }\end{array}$ & $\begin{array}{c}\text { Medium } \\
\text { presence of fat }\end{array}$ & $\begin{array}{c}\text { Larger amounts } \\
\text { of fat }\end{array}$ & $\begin{array}{c}\text { Distinct } \\
\text { presence of fat }\end{array}$ \\
\hline Kidneys & $\begin{array}{l}\text { Insignificantly } \\
\text { covered }\end{array}$ & Poorly covered & $\begin{array}{c}\text { About } 2 / 3 \\
\text { covered }\end{array}$ & $\begin{array}{l}\text { Over } 2 / 3 \\
\text { covered }\end{array}$ & Fully covered \\
\hline
\end{tabular}

All data were developed statistically by using program Statistica for Windows, Computer program manual. StatSoft.Inc.(2007), Tulsa, OK. Significance of mean differences was estimated by Student's t- test.

\section{Results and Discussion}

In Table 2. the results of the effect of crossing domestic Simmental with French fattening breeds on conformation and fat cover were presented. In regard to conformation score of carcasses statistically significant differences were 
demonstrated $(p<0,01)$ between crosses and domestic Simmental cattle, whereas between the crosses genotypes no statistical significance of differences was established (Graph 1).

Table 2. Effect of crossing of domestic Simmental cattle with Charolais and Limousine on conformation and fat cover

\begin{tabular}{|l|c|c|c|c|c|c|c|}
\hline \multirow{2}{*}{ Traits } & \multicolumn{3}{|c|}{ Genotype } & \multirow{2}{*}{$\mathrm{F}$} & \multicolumn{3}{|c|}{ T test } \\
\cline { 8 - 9 } \cline { 7 - 8 } & $\mathrm{G} 1$ & $\mathrm{G} 2$ & $\mathrm{G} 3$ & & $\mathrm{G} 1 / \mathrm{G} 2$ & $\mathrm{G} 1 / \mathrm{G} 3$ & $\mathrm{G} 2 / \mathrm{G} 3$ \\
\hline $\begin{array}{l}\text { Final body } \\
\text { weight, kg }\end{array}$ & 579 & 590 & 621 & $* *$ & $\mathrm{~ns}$ & $* *$ & $*$ \\
\hline $\begin{array}{l}\text { Carcass } \\
\text { weight, kg }\end{array}$ & 324.1 & 360.0 & 372.6 & $* *$ & $* *$ & $* *$ & $\mathrm{~ns}$ \\
\hline $\begin{array}{l}\text { Dressing } \\
\text { percentage, } \%\end{array}$ & 55.7 & 59.8 & 59.9 & $* *$ & $* *$ & $* *$ & $\mathrm{~ns}$ \\
\hline $\begin{array}{l}\text { Total } \\
\text { conformation } \\
\text { score (1-5) }\end{array}$ & 3.40 & 3.90 & 3.94 & $* *$ & $* *$ & $* *$ & $\mathrm{~ns}$ \\
\hline $\begin{array}{l}\text { External fat } \\
\text { cover (1-5) }\end{array}$ & 3.72 & 3.63 & 3.55 & $* *$ & $\mathrm{~ns}$ & $* *$ & $\mathrm{~ns}$ \\
\hline $\begin{array}{l}\text { Internal fat } \\
\text { cover (1-5) }\end{array}$ & 3.23 & 3.21 & 3.27 & $\mathrm{~ns}$ & $\mathrm{~ns}$ & $\mathrm{~ns}$ & $\mathrm{~ns}$ \\
\hline $\begin{array}{l}\text { Total fat } \\
\text { cover (1-5) }\end{array}$ & 3.47 & 3.42 & 3.41 & $\mathrm{~ns}$ & $\mathrm{~ns}$ & $\mathrm{~ns}$ & $\mathrm{~ns}$ \\
\hline
\end{tabular}

* denominates statistically significant differences at the level of $\mathrm{P}<0.05 ; * *$ at the level of $\mathrm{P}<0.01$; ns-at the level of $\mathrm{P}>0.05$

Crosses with Charolais realized the highest conformation score $(3,94)$, with the highest scores for round conformation $(3,77)$ and shoulder $(4,06)$, whereas crosses with Limousine had in average slightly more developed central carcass part $(4,02)$, but without any statistically significant differences. These results are in concordance with research results obtained by Aleksić et al. (1999) where positive deviations of crosses with Charolais $(+0,13)$ and Limousine $(+0,03)$ to general average $(4,65)$ were determined in conformation evaluation, whereas domestic breed demonstrated negative deviation of $-0,16$.

In research by Chambaz et al. (2003), carcasses obtained from Simmental cattle demonstrated the worst conformation compared to Charolais and Limousine cattle carcasses which were significantly heavier. These authors established no significant effect of genotype on thickness of subcutaneous tissue and cover of carcass with fat. 


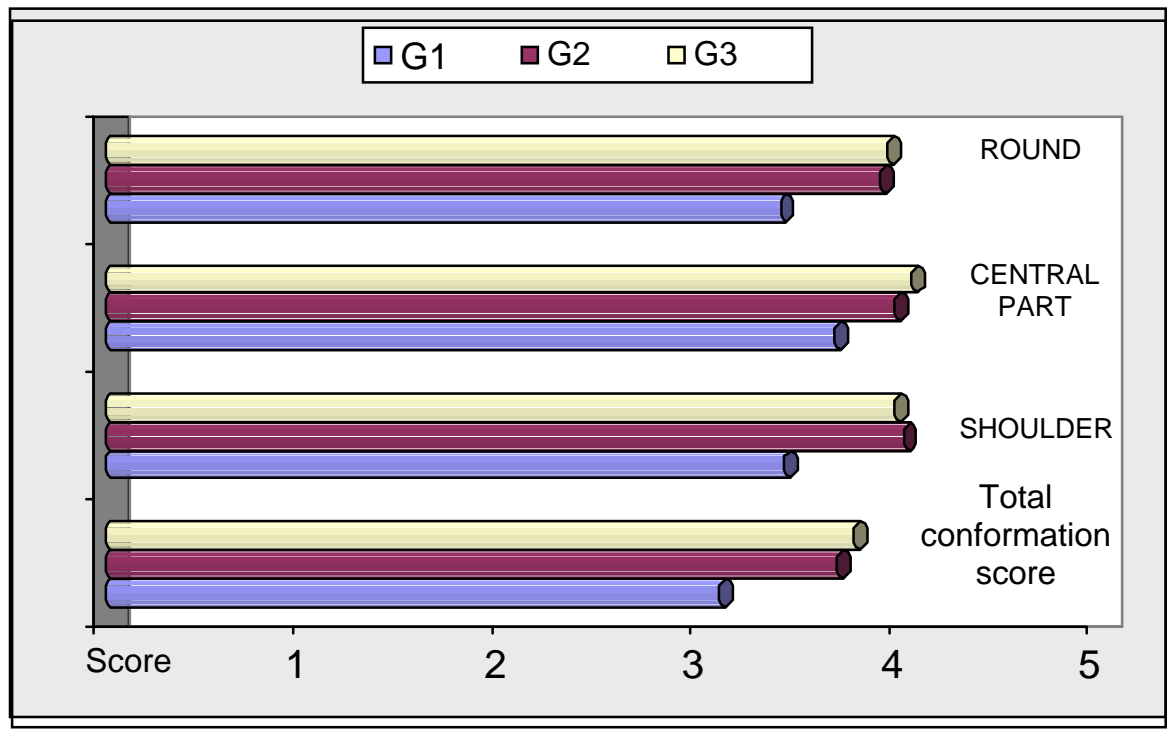

Graph 1. Differences between genotypes in carcass conformation

In regard to total cover of external carcass domestic Simmental cattle has significantly more fat only compared to crosses with Charolais. The most expressive differences, significant at the level of $p<0,01$, were present in case of cover of rounds with fat, where crosses with Charolais and Limousine were scored 3,27 and 3,30, and domestic Simmental cattle 3,44. However, it can be concluded that all three genotype groups had desirable cover of rounds with fat from the aspect of assessment of carcass quality.

In regard to evaluation of internal fat cover, final analysis of the sum of individual scores showed that differences between three genotypes had no statistical significance. However, results of partial scores of cover of chest and pelvic cavities with fat, as well as kidneys, showed significant differences. So the highest presence of fat on the chest cavity was recorded in heads of domestic Simmental cattle $(3,61)$ ad the lowest in crosses with Limousine $(2,83)$ with statistically significant differences at the level of $p<0,01$. Differences between genotypes in fat cover are presented in Graph 2. 


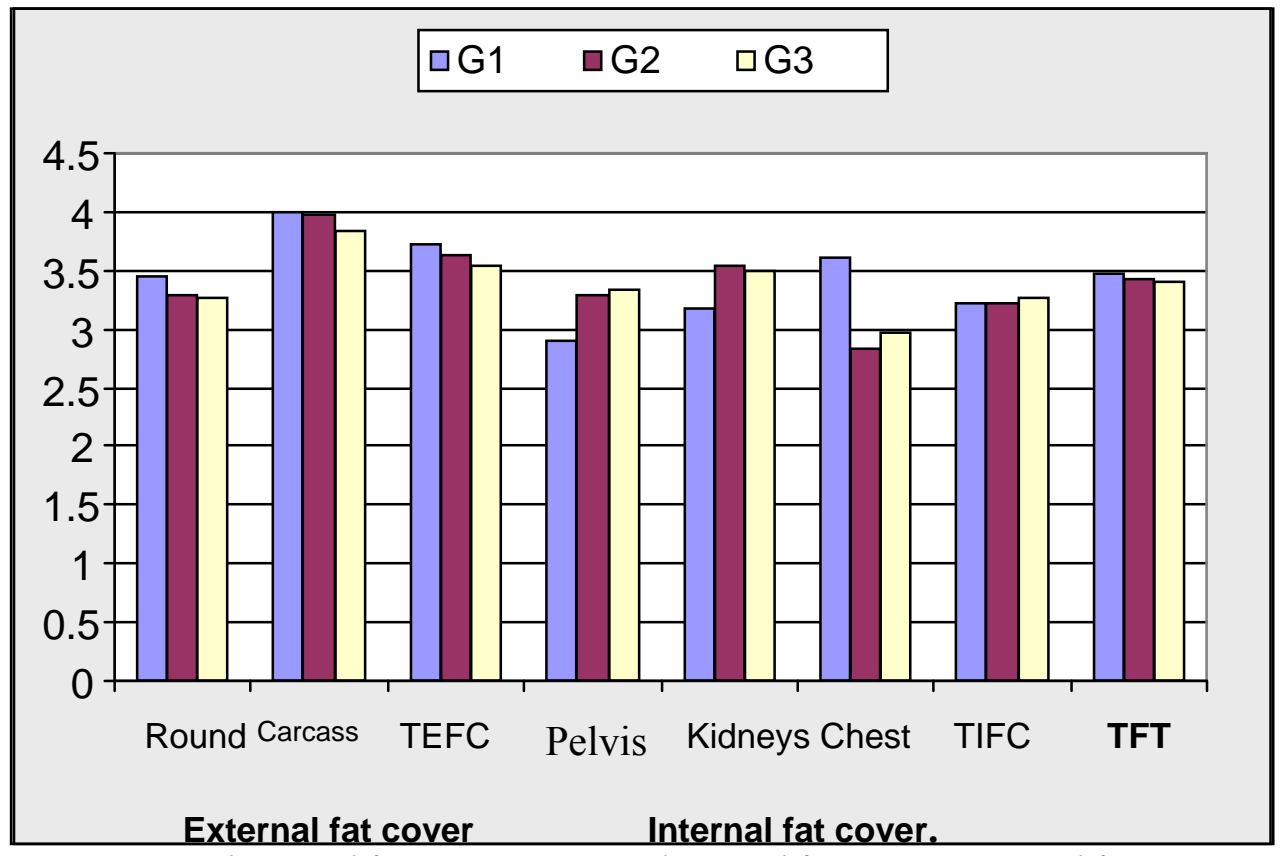

TEFC-Total external fat cover; TIFC-Total internal fat cover; TFT-Total fat cover

\section{Graph 2. Differences between genotypes in fat cover}

Presence of fat in pelvic cavity was more distinct in crosses with Charolais $(3,34)$ and Limousine $(3,28)$, where also the cover of kidneys with fat was better $(3,50$ and 3,53$)$ compared to domestic breed $(3,17)$. These significances were also significant at the level of $\mathrm{p}<0,01$.

Results of this research are in concordance with results obtained by Aleksić et al. (1999) where carcass cover with fat established in domestic breed was also more distinct compared to crosses of F1 generation with statistical significance of differences at the level of $p<0,05$. Deviation from the average $(4,5)$ for this trait was negative for crosses with Charolais and Limousine $(-0,05$ and for domestic breed - 0,06 .

Dhuyvetter et al. (1985) established slightly lower presence of internal and external fat in crosses with Charolais compared to crosses with Limousine. This corresponds to differences in values of scores for internal and external carcass cover of said genotypes obtained in this experiment. 


\title{
Conclusion
}

Based on previously presented results it can be concluded that crossing of domestic Simmental breed with French fattening breeds resulted in significant improvement in conformation in F1 crosses, especially in regard to high quality sections (round, back and loin).

Fat layers on outside carcass were significantly greater in domestic Simmental cattle compared to crosses with Charolais. Despite the aforementioned, positive effects of fat cover on the carcass quality, this can not be considered desirable from the standpoint of fat content in carcass and the meat given the high correlation of these two properties.

In regard to total internal fat cover of carcass, no statistically significant differences were established between genotypes. However, it can be concluded that distribution of fat tissue in depots between domestic breed and crosses varied. Also, whereas in case of domestic Simmental cattle fat is deposited in chest cavity, in crosses this occurred in pelvic cavity, which resulted in better cover of kidneys and better grading of the carcass quality.

\section{Acknowledgment}

Research was financed by the Ministry of Education and Science Republic of Serbia, project TR 31053.

\section{Uticaj ukrštanja domaće simentalske rase i francuskih tovnih rasa na konformaciju i prekirvenost junećih trupova lojem}

\author{
D. Ostojić-Andrić, S. Aleksić, M.M. Petrović, S. Hristov, V. Pantelić, Ž. Novaković, \\ D. Nikšić
}

Rezime

Ocena konformacije i prekrivenosti junećih trupova lojem ima veliki značaj u savremenim sistemima ocene kvaliteta trupova. Na ovaj način postiže se odgovarajuća cena za svaku klasiranu polutku prema zahtevima potrošača. U ovom radu ispitivan je uticaj eksperimentalnog ukrštanja domaće simentalske rase sa šarole i limuzin rasom $(\mathrm{N}=96)$ na konformaciju i prekrivenost junećih trupova lojem. Ispitivanje je obuhvatilo ocenu pomenutih osobina na celim trupovima kao i parcijalno na određenim delovima trupova a prema odgovarajućoj linearnoj skali ocene (1-5). U odnosu na ocenu konformacije trupova utvrđene su statistički 
značajne razlike $(\mathrm{p}<0,01)$ između meleza i domaće simentalske rase. Melezi Šarolea postigli su najbolju ocenu konformacije trupova $(3,94)$, konformacije buta $(3,77)$ i plećki $(4,06)$. Značajno više masnog tkiva na spoljašnjem delu trupa utvrđeno je kod domaće simentalske rase. $(3,44)$ u poređenju sa melezima Šarolea $(3,27)$. Prisustvo masti u karličnoj šupljini bilo je izraženije kod Šarole $(3,34)$ i Limuzin meleza $(3,28)$, sa boljom ocenom prekrivenosti bubrega $(3,50$ and 3,53$) \mathrm{u}$ odnosu na domaću simentalsku rasu $(3,17)$.

\section{References}

ALEKSIĆ S., MIŠČEVIĆ B., PETROVIĆ M.M., ILIĆ Z., TOMAŠEVIĆ D. (1999): The influence of genotype on the quality of young bull carcass. Biotechnology in Animal Husbandry 15, 3-4, 53-59.

CHAMBAZ A., SCHEEDER M.R.L., KREUZER M., DUFEY P.A. (2003): Meat quality of Angus, Simmental, Charolais and Limousine steers compared at the same intramuscular fat content. Meat Science, 63, 491-500.

DHUYVETTER J.M., FRAHM R.R., MARSHALL D.M. (1985): Comparison of Charolais and Limousine as terminal cross sire breeds. Journal of Animal Science, 60, 935.

MAY S.G., DOLEZAL H.G., GILL D.R., RAY F.K., BUCHANAN D.S. (1992): Effect of days fed, carcass grade traits, and subcutaneous fat removal on postmortem muscle characteristics and beef palatability. Journal of Animal Science, 70, 2, 444-453.

MARSHALL D.M. (1994): Breed differences and genetic parameters for body composition traits in beef cattle. Journal of Animal Science, 72, 2745-2755.

OSTOJIĆ-ANDRIĆ D., BOGDANOVIĆ V., ALEKSIĆ S., PETROVIĆ M.M., MIŠČEVIĆ B., PANTELIĆ V., NOVAKOVIĆ Ž. (2008): The effect of crossing of domestic Simmental breed with French fattening breeds on quality of beef carcasses, Journal of Mountain Agriculture on the Balkans, 11, 4, 673-683.

SEUROP classification - REVIEW OF THE EU CARCASE CLASSIFICATION FOR BEEF AND SHEEP (2008): A report for defra prepared by AHDB. www.defra.gov.uk

STATISTICA FOR WINDOWS (2007): Computer programm manual. StatSoft.Inc., Tulsa, OK.

USDA Beef grade - UNITED STATES STANDARDS FOR GRADES OF CARCASS BEEF (1997): United States Department of Agriculture, Agricultural Marketing Service, Livestock and Seed Division. www.ams.usda.gov 